DOI 10.4467/2543733XSSB.17.003.7249

JAROSŁAW STOLICKI

Uniwersytet Jagielloński

\title{
DZIAŁANIA JANA III SOBIESKIEGO W CELU WZROSTU ZNACZENIA RZECZYPOSPOLITEJ W EUROPIE W LATACH 1674-1683
}

\begin{abstract}
Słowa kluczowe: Jan III Sobieski, wojny polsko-tureckie, polityka bałtycka, koalicja antyturecka
\end{abstract}

Panowanie Jana III Sobieskiego przypadło na okres upadku znaczenia międzynarodowego Rzeczypospolitej ${ }^{1}$. Wybuch powstania Chmielnickiego zapoczątkował jej kryzys, a kolejne wydarzenia przynosiły osłabienie państwa, popadającego w coraz większą izolację. W konsekwencji doprowadziło to do poddania się Bohdana Chmielnickiego Moskwie oraz najazdu wojsk carskich. Dodatkowo kraj zaczął pogrążać się w chaosie wewnętrznym, do którego narastania przyczyniła się słabość międzynarodowa. Kryzys został pogłębiony przez najazd Szwedów, a potop przyniósł ogromne zniszczenia ekonomiczne. Najpoważniejszą międzynarodową konsekwencją wojny było umocnienie pozycji elektora brandenburskiego Fryderyka Wilhelma, który uzyskał suwerenność w Prusach. Nie powiodła się podjęta po potopie elekcja vivente rege kandydata francuskiego. Wojna domowa zaangażowała elity tak silnie, że państwo nie mogło skoncentrować się na pomyślnym dokończeniu wojny z Moskwą. Doprowadziło to do podpisania traktatu andruszowskiego, który badacz ocenił jako przełomowe wydarzenie w dziejach Europy Wschodniej². Podjęta przez nowego władcę, Michała Korybuta Wiśniowieckiego, reorientacja polityki międzynarodowej nie miała na celu doprowadzenia do odbudowy pozycji międzynarodowej państwa polsko-litewskiego, lecz była skutkiem sytuacji wewnętrznej. Podkanclerzy

1 Tezę taką przedstawił K. P i w ar s k i, Osłabienie znaczenia międzynarodowego Rzeczypospolitej $w$ drugiej połowie XVII w., „Roczniki Historyczne”, R. XXIII: 1957, s. 221-258. Potem w licznych pracach rozwinął ją Zbigniew Wójcik. Ważny jest artykuł: Zmiana $w$ uktadzie sit politycznych $w$ Europie środkowo-wschodniej w drugiej połowie XVII wieku, „Kwartalnik Historyczny”, R. LXVII: 1960. Podsumowaniem są: obszerny fragment autorstwa tego historyka: Dyplomacja polska w okresie wojen drugiej połowy XVII w. (1648-1699), [w:] Historia dyplomacji polskiej, t. II, 1572-1795, Warszawa 1982, s. 163-330 oraz Z. W ó j c i k, Jan Sobieski 1629-1696, Warszawa 1983.

${ }^{2}$ Z. W ój c i k, Traktat andruszowski 1667 roku i jego geneza, Warszawa 1959. 
Andrzej Olszowski szukał sojuszu z Habsburgami w celu osłabienia wpływów stronnictwa profrancuskiego. Pod koniec panowania króla Michała na Rzeczpospolitą spadł groźny najazd turecki, którego konsekwencją była utrata Kamieńca oraz upokarzający traktat w Buczaczu.

Dnia 20 maja 1674 r. nowym królem został obrany Jan Sobieski. Dominująca wśród szlachty chęć obioru władcą Piasta oraz obawa przed kolejnym najazdem nieprzyjacielskim skłoniły obywateli do wyboru zasłużonego wodza. Za panowania swego poprzednika był on przywódcą opozycji spiskującej przeciw Wiśniowieckiemu. Z tego powodu nie cieszył się w społeczeństwie powszechnym uznaniem. Aureola zwycięstwa chocimskiego usunęła jednak wątpliwości szlachty.

Jan Sobieski został królem jako kandydat stronnictwa profrancuskiego, m.in. też dzięki wsparciu (zwłaszcza finansowemu) Ludwika XIV. Elekcja przypadła na czas wojny między Francją a Holandią i Habsburgami. Obie strony starały się o szukanie sojuszników w tym konflikcie. Król Słońce w czasie bezkrólewia początkowo dążył jedynie do uniemożliwienia wyboru kandydata habsburskiego. Wydarzenia na polu elekcyjnym przebiegały jednak bardzo korzystnie dla Ludwika XIV. Elekcja Sobieskiego doprowadziła do zerwania sojuszu Francji z elektorem brandenburskim Fryderykiem Wilhelmem, który zaskoczony i zaniepokojony jej wynikiem, poczuł się oszukany przez Francuzów. Porzucił więc obóz profrancuski i związał się z Habsburgami ${ }^{3}$. W tej sytuacji wspólne interesy skłaniały monarchę polskiego i francuskiego do współpracy. Partnerem dla Ludwika XIV był nowy król polski Jan Sobieski, a nie Rzeczpospolita. Szlachta nie chciała bowiem kolejnego konfliktu i to z sąsiadem, który nie był traktowany jako zagrożenie. W Polsce pamiętano o nieprzyjaznych działaniach elektora, wyrażano nawet $\mathrm{z}$ ich powodu oburzenie, ale priorytetem były sprawy południowe i wschodnie. Ponadto z faktycznego zagrożenia ze strony Brandenburgii zdawały sobie sprawę jedynie jednostki. Sobieski być może - myślał o aspektach dynastycznych. Trzeba jednak ocenić, że interes rodziny Sobieskich był zgodny nie tylko z interesem Rzeczypospolitej, ale wręcz z polską racją stanu. Monarcha polski prowadził więc politykę sekretną, która była ukrywana przed szlachtą, a zwłaszcza przed jego przeciwnikami. Uprawianie takiej polityki było tym bardziej logiczne, że stanowiła ona kontynuację działań, które doprowadziły Jana Sobieskiego do korony. Oczywiście nie można było ukryć rokowań z posłami francuskimi, którzy przebywali w Rzeczypospolitej. W związku z tym dyplomaci cesarza i elektora, wspomagani przez nuncjusza, starali się, aby Rzeczpospolita nie mogła wejść w orbitę wpływów francuskich. Dążyli do zdyskredytowania działań monarchy, aby osłabić jego pozycję wśród szlachty, i liczyli, że wojna polsko-turecka będzie trwała jak najdłużej. Po elekcji Sobieski skupił się głównie na działaniach wojennych na Ukrainie, stąd nie podejmował innych kwestii, zwłaszcza mogących osłabić Rzeczpospolitą. Fryderyk Wilhelm, zajęty konfliktem nad Renem, nie wywiązywał się ze zobowiązań, zgodnie z którymi był zobligowany do dostarczenia pomocy, co zirytowało króla polskiego i przyśpieszyło jego rozmowy $\mathrm{z}$ ambasadorem Francji Forbin-Jansonem oraz przybyłym mu do pomocy margrabią de Bethune. W tych rokowaniach trzecim partnerem była Szwecja, tradycyjny sojusznik Francji, mająca działać przeciw Brandenburgii. Na rzecz układu polsko-szwedz-

\footnotetext{
${ }^{3} \mathrm{Na}$ ten temat praca magisterska I. Karwat, Dyplomacja francuska w Rzeczypospolitej w dobie bezkrólewia i elekcji 1673-1674, Kraków 2011 (Zakład Historii Polski Nowożytnej IH UJ).
} 
kiego pracowali dyplomaci francuscy. Przez pewien czas Sobieski obawiał się nadmiernego zainteresowania Szwecji terenami pruskimi, bowiem w Rzeczypospolitej pamiętano o niedawnych, zaborczych dążeniach Szwedów wobec ziem nadbałtyckich. W drugiej połowie 1674 r. elektor wyruszył z armią przeciw Francji, wspierając wojska cesarskie. Niedługo potem Fryderyk Wilhelm wrócił znad Renu, zawiedziony brakiem sukcesów na zachodzie i zaalarmowany działaniami Szwecji, która zaatakowała Brandenburgię. Niemniej druga połowa 1675 r. minęła pod znakiem sukcesów wojsk elektorskich w walkach ze Szwedami. Wcześniej jednak, 11 czerwca 1675 r. doszło do zawarcia układu polsko-francuskiego w Jaworowie. Strony deklarowały, że mają wspólne cele, zaś Ludwik XIV jest zainteresowany, aby Prusy Książęce zostały przejęte przez jego partnera. Zobowiązał się do popierania interesów polskich i pomocy w zakończeniu wojny z Portą; po tym zaś miał udzielać Sobieskiemu w przyszłym konflikcie subsydiów finansowych oraz wsparcia dyplomatycznego ${ }^{4}$. Pieniądze otrzymane od Francji król polski miał przeznaczyć na prywatne zaciągi, które były polskim wkładem w przyszłą walkę przeciw Fryderykowi Wilhelmowi. Ponadto Sobieski liczył na aktywne poparcie społeczeństwa Prus Książęcych. Bezwzględne łamanie praw stanów pruskich przez elektora powodowało wzrost oporu tychże stanów. Ponadto sukcesy elektora w Rzeszy skłoniły króla i Szwedów do podjęcia rozmów na temat skoordynowania działań w Prusach. Władca liczył, że niechęć szlachty wobec elektora nie doprowadzi do zdecydowanych wystąpień przeciw nowej polityce.

Jest wreszcie i kolejny zamysł, leżący na końcu tych wielkich zamierzeń, ale niewątpliwie odpowiadający intencjom układających się stron. Cesarz ,posiadał prastarą dzielnicę piastowską - Śląsk" ‘. Bezsprzecznie zamiary dotyczące Śląska były raczej marzeniami niż dążeniami monarchy. Plany królewskie zasługują na określenie wielkie, ponieważ były realistyczne. Nie było intencją monarchy wywoływanie nowych konfliktów z sąsiadami, z którymi dotychczas relacje układały się poprawnie, ponieważ nosiłoby to charakter awantury. Działania przeciw elektorowi miały być podjęte w momencie zakończenia konfliktu z Portą i bezpośrednio nie przez Rzeczpospolitą. Zamysł przypomnienia o Śląsku mógł być wprowadzony w życie wtedy, gdy sytuacja we wspomnianym konflikcie zdecydowanie przechyliłaby się na niekorzyść obozu cesarskiego.

Już wiedza o porozumieniu polskiego władcy z Królem Słońce szachowała elektora brandenburskiego, ale niepokoiła też Habsburgów. Równocześnie Sobieski zdawał sobie sprawę, że nie może podejmować tych działań wbrew opiniom szlachty. Musiał więc zachować wielką ostrożność, aby nie zrazić obywateli. Trzeba też przypomnieć, że w czasie elekcji kandydatura Sobieskiego spotkała się z przeciwdziałaniem znacznej części Litwy. Wśród jego przeciwników łatwy posłuch znajdowała agitacja brandenburska. Elekcja króla, przyjęta z dużym entuzjazmem przez szlachtę, sprawiła, że wśród jego zwolenników pojawiły się pomysły usprawnienia państwa. W propagandzie przeciwników dworu były one przedstawiane jako zamysły absolutystyczne i zamachy na wolności szlacheckie. Prowadzenie zaś wojny z Portą wymagało od szlachty wyrzeczeń, co też dawało argumenty jego przeciwnikom, szermującym hasłami, że wojna jest prowadzona w imię interesów

${ }^{4}$ K. P i wars ki, Polityka baltycka Jana III w latach 1675-1679, [w:] Księga pamiatkowa ku czci Profesora dra Wacława Sobieskiego, Kraków 1932, t. I, s. 197-265; J. Wolińs k i, Sprawa pruska 1673-1675 i traktat jaworowski, [w:] i d e m, Z dziejów wojny i polityki w dobie Jana Sobieskiego, Warszawa 1960, s. 16-56.

5 J. Wol iń s k i, Król Jan III Sobieski. W 250-letnią rocznicę śmierci, Warszawa 1946, s. 27-28. 
obcych, że król dąży do osiągnięcia własnych celów i zamierza wzmocnić wojsko, aby ograniczyć prawa szlachty. Równocześnie ważnym zadaniem nowego monarchy było zapewnienie sobie spokoju ze strony cesarza. Habsburgowie tradycyjnie posiadali spore wpływy w Rzeczypospolitej, czego Sobieski był świadomy, nie leżało zatem w interesie władcy angażowanie przeciw sobie ich stronników. Musiał więc Sobieski deklarować chęć wsparcia pewnych działań Francji skierowanych przeciw Habsburgom, ale ich właściwie nie podejmować ${ }^{6}$.

Przy tym najważniejsza była tocząca się wojna z Portą. Sobieski nie miał innego wyjścia, jak tylko zakończyć ją pomyślnie, aby w ogóle myśleć o podjęciu jakichkolwiek innych działań. Stosunki z Moskwą układały się wówczas chłodno, doświadczenia ostatnich lat wykazały, że nie było możliwe uzyskanie stamtąd wsparcia przeciw Imperium Osmańskiemu. Co gorsza, na początku 1674 r. nastąpił zwycięski marsz wojsk moskiewskich na ziemie Ukrainy Prawobrzeżnej ${ }^{7}$. Państwo carów wykorzystało sytuację w wojnie polsko-tureckiej, kiedy wojska osmańskie wycofały się za Dunaj, zaś polskie, z powodu bezkrólewia, nie podejmowały działań zbrojnych. Moskwa zdecydowała się na opanowanie Ukrainy Prawobrzeżnej, która formalnie znajdowała się pod zwierzchnictwem tureckim. Niezbyt silne oddziały kozackie uznały zwierzchnictwo moskiewskie. Wspomniane posunięcia wskazywały na dążenia państwa carów do zjednoczenia Ukrainy i znacznego umocnienia się tam Moskwy. Był to bardzo groźny prognostyk dla Rzeczypospolitej, co dostrzegały elity państwa. W tej sytuacji Sobieski musiał rozpocząć akcję szukania sojuszników wśród Kozaków. Dotychczasowe doświadczenia uczyły, że działania te muszą być poparte siłą zbrojną. Właśnie silna armia była czynnikiem, który uratował wpływy moskiewskie na Ukrainie Lewobrzeżnej, kiedy wojska polskie odnosiły sukcesy. Utrzymała ona posłuszeństwo wśród ludności. Jan Sobieski zaraz po elekcji podjął zatem wyprawę, której celem było zbrojne odzyskanie prawobrzeżnej Ukrainy, gdzie tymczasem zmieniła się sytuacja militarna, ponieważ Rosjanie zostali wyparci przez Turków. Wojna ta doczekała się niedawno opracowania ${ }^{8}$, więc należy zwrócić uwagę na towarzyszące jej działania polityczne. W wydanych 16 listopada 1674 dwóch uniwersałach do mieszkańców Ukrainy król poinformował o wyprawie, której zadaniem jest „dźwignięcie Waszmości Waszych z ciężkiej niewoli bisurmańskiej", lonych cerkwiach i innych okrucieństwach protekcji muzułmańskiej. Zadeklarował się jako ważny sojusznik, obrońca ludności i religii, oraz przypomniał o wspólnych prawach i wolnościach. Musiał starać się też o pozyskanie Piotra Doroszenki, który wcześniej, po przejęciu władzy wśród Kozaków uznał protekcję turecką. W tym celu wysłał do niego

\footnotetext{
${ }^{6} \mathrm{O}$ działaniach Jana III podejmowanych w celu uspokojenia cesarza J. Wol iń s k i, Poselstwo Krzysztofa Schaffgotscha na elekcję polska 1674 r., [w:] i d e m, Z dziejów wojny..., s. 100-124.

7 J. Woliń s ki, Król Jan III a sprawa Ukrainy 1674-1675, Warszawa 1934.

${ }^{8}$ M. Wag ner, Wojna polsko-turecka w latach 1672-1676, t. I-II, Zabrze 2009. Autor podobnie ocenił koncepcje polityczne Jana III na Ukrainie (t. II, s. 120).

${ }^{9}$ Uniwersał Jana III do duchowieństwa grecko-ruskiego, 16 XI 1674, w obozie pod Barem, Biblioteka Czartoryskich w Krakowie, Teka Naruszewicza 172, s. 537-539; Uniwersał Jana III do Kozaków, ibidem, s. 541-542 (dalej B. Czart., TN).
} 
posłów, którymi byli: prawosławny episkop lwowski Józef Szumlański oraz podsędek chełmiński Stanisław Morsztyn ${ }^{10}$. Doroszenko, zaskoczony wkroczeniem wojsk polskich, prowadził grę dyplomatyczną na przeczekanie, rokował z monarchą, ale liczył na wojska tureckie. O jego prawdziwych zamiarach świadczy uniwersał do ludności, w którym informował o wkroczeniu armii polskiej, próbach nawiązania współpracy, ale podsumował: „z dawna znając lackie chytre omamy, a za omamami następujące tyraństwa”" ${ }^{11}$ i wezwał do działań przeciw tym wojskom i łączenia się z siłami tatarskimi.

Mimo wrogiej postawy Doroszenki Sobieski podejmował wysiłki, które mogły wzmocnić opcję propolską na Ukrainie. Kiedy rozeszły się wiadomości o śmierci hetmana kozackiego, król wydał głośny uniwersał do Kozaków ${ }^{12}$. Warto tu zauważyć, że sytuacja w tym czasie, którą znamy z listów wysłanych przez monarchę do senatorów, była bardzo trudna. Osiągnięto wprawdzie sukcesy wojskowe, zajmując twierdze podolskie i ukrainne, ale były one niewspółmierne do włożonego wysiłku. Ciężkie położenie wojska pogłębiła, kolejna już, dezercja hetmana litewskiego M. Paca. Działania dyplomatyczne nie przyniosły efektów, wysłannicy do Kozaków i Tatarów są przez nich przetrzymywani, zaś elektor odwołał posiłki, do udzielenia których zobowiązywało go prawo. Na domiar złego podczas komisji andruszowskiej z Moskwą nie udało się uzyskać żadnych rezultatów, a relacje z nią pozostają trudne: „na listy zaś nasze gęste ledwo jeden dopiero przez Kijów i to uszczypliwy respons doszedł nas"13. Wiadomość o śmierci Doroszenki wydawała się więc dawać nadzieje na umocnienie pozycji Rzeczypospolitej na Ukrainie.

We wspomnianym wyżej uniwersale z 25 lutego 1675 r. monarcha przedstawił nieszczęścia, które spadły na Ukrainę na skutek działań zwolenników Porty: zniszczenie miast $\mathrm{i}$ cerkwi oraz wyginięcie narodu ruskiego wywiezionego $\mathrm{w}$ jasyr. W razie wyboru hetmana przychylnego Rzeczypospolitej, król obiecywał amnestię oraz zachowanie wolności i swobód.

Kiedy wieści o śmierci Doroszenki okazały się fałszywe, Sobieski podjął kolejne działania. Ich celem było wykorzystanie stronników polskich wśród Kozaków, w których gronie wyróżniał się ataman koszowy Iwan Sirko. Monarcha wysłał do niego poselstwo ${ }^{14}$. Pełniący funkcję posła Sz. Zawisza miał wyjaśnić motywy wkroczenia wojsk polskich na Ukrainę, zaproponować współpracę i posiłki, a ponadto wybadać, czy Sirko, zasłużony dla spraw Rzeczypospolitej, nie oczekuje buławy, ,ponieważ już nie ma żadnej nadziei, aby się Doroszenko opamiętał”. List z propozycją współpracy został wysłany do setnika targowickiego Kwaszy, natomiast uniwersały do serdiuków pawołockich i do czerni ${ }^{15}$. Warto jeszcze zwrócić uwagę, że wszelkie akcje dyplomatyczne były ściśle skorelowane z poczynaniami wojennymi króla. Próba pozyskania Kozaków przyniosła pewne efekty. W służbie Rzeczypospolitej znajdowała się część wojska kozackiego pod dowództwem Ostafieja Hohola.

\footnotetext{
${ }^{10}$ Instrukcyja od króla JM. do Kozaków, Bibl. Czart., rkps 431, s. 157-159.

${ }^{11}$ Uniwersał Doroszenki do ludności Ukrainy, w Czehrynie 13 XII 1674, B. Czart., TN 172, s. 593-594.

${ }_{12}$ Pisał o tym Z. W ó j c i k, Jan Sobieski..., s. 245.

${ }^{13}$ Kopia deliberatoriarum od Króla JMci do ichm. panów senatorów, de data 10 II 1675 z Bracławia, Bibl. Czart., rkps 431, s. 266-268.

${ }^{14}$ Kopia listu do atamana koszowego, z Bracławia 14 III 1675, Bibl. Czart., rkps 423, s. 249; Instrukcyja ur. Szymonowi Zawiszy, rotmistrzowi JKMci na Zaporoże ordynowanemu dana, dnia 14 III 1675, ibidem, s. 235-237; Memoriał ur. Zawiszy..., ibidem, s. 235-241.

${ }^{15}$ Ibidem, s. 243, 257-258.
} 
Monarcha liczył też na pokojowe i kompromisowe zakończenie wojny z Portą. Rok 1675 minął pod znakiem wielu działań dyplomatycznych. Mediację prowadzili lennicy Imperium Osmańskiego, z którymi próbował porozumieć się Sobieski. Samodzielność chanatu krymskiego w owym czasie znacznie osłabła, co było naturalną konsekwencją faktu, że Porta musiała ograniczyć swobodę poczynań Krymu, a i tak kolejni chanowie nie we wszystkim spełniali oczekiwania Stambułu. Tatarzy regularnie podejmowali działania mediacyjne w konflikcie polsko-tureckim. Niechętnie brali też udział w samych walkach. Dodatkowo umocnienie się Moskwy spowodowało na Krymie obawy przed zagrożeniem moskiewskim, dlatego też chan wskazywał w Stambule na konieczność działań zbrojnych przeciw państwu carów, aby wyprzeć z Ukrainy rozszerzające się wpływy moskiewskie ${ }^{16}$.

Kolejne działania podjął Jan III w księstwach naddunajskich ${ }^{17}$. Próba zbudowania stronnictwa popierającego interesy polskie w Mołdawii była naturalna. Zabiegi Sobieskiego poszły dalej; celem było osłabienie wpływów tureckich na Wołoszczyźnie oraz w Siedmiogrodzie. Niemniej było to zadanie bardzo trudne, ponieważ księstwa były terenami, przez które przechodziły wojska obu stron; w dodatku żadnych rezultatów nie przyniosła interwencja wojsk polskich w Mołdawii po zwycięstwie chocimskim, a zajęte wówczas twierdze zostały utracone po ponad pół roku. Zwolennik Rzeczypospolitej Stefan Petryczejko przebywał na emigracji w Polsce i liczył na odzyskanie tronu w Jassach, gdzie istniało zresztą dość silne stronnictwo propolskie.

Działania dyplomatyczne przyniosły bardziej konkretne zainteresowanie sprawami polskimi we Francji i Austrii ${ }^{18}$. Ludwik XIV potrzebował zakończenia wojny polsko-tureckiej. W konsekwencji Habsburgowie zacieśnili relacje z Moskwą, która w drugiej połowie 1675 r. podejmowała działania mające zdecydowanie charakter antypolski. Nastąpiła interwencja moskiewska na Prawobrzeżu, zajęcie Czehrynia i usunięcie Doroszenki. W Moskwie doszło do rokowań zakończonych wstępnym porozumieniem między dyplomatami cesarskimi i rosyjskimi, dla których Rzeczpospolita (a konkretniej symbolizująca ją polityka Jana Sobieskiego) była zagrożeniem.

Z. Wójcik zwrócił uwagę na posunięcia dyplomacji francuskiej w Stambule w latach 1674-1676, próbującej działać na rzecz zakończenia wojny polsko-tureckiej na honorowych dla obu stron warunkach ${ }^{19}$. Francja nawet w 1674 r. chciała podjąć się mediacji w konflikcie, ale sugestie takie nie zostały przyjęte przez stronę osmańską. Król Słońce, wysyłając swojego ambasadora do Adrianopola w 1676 r., polecił mu podjęcie działań na rzecz podpisania pokoju polsko-tureckiego. Ludwik XIV, zwracając się również do dyplomatów osmańskich, podkreślał, że w przypadku zawarcia pokoju z Polską, ta może wówczas udzielić wsparcia powstańcom antyhabsburskim na Węgrzech. Poczynania te nie przyniosły jednak powodzenia, z powodu narastających tendencji wojennych w Stambule, a i relacje między Wersalem i Stambułem nie układały się wówczas najlepiej.

${ }^{16}$ O postawie Tatarów pisali J. Woliński i Z. Wójcik; warto w tym miejscu wymienić: J. Woliń s ki, Pośrednictwo tatarskie $w$ wojnie polsko-tureckiej 1674-1675, [w:] i d e m, Z dziejów wojny..., s. 139-159. Należy tutaj wskazać, że w działaniach tych uczestniczył Doroszenko, List Piotra Doroszenki do Jana III z taboru pod Śmiałą 7 IV 1675, B. Czart., rkps 423, s. 269.

${ }_{17}$ I. C z a m á s k a, Oswobodziciel czy najeźdźca? Polityka Jana III Sobieskiego wobec hospodarstw Motdawii i Woloszczyzny, „Roczniki Historyczne”, R. LV-LVI: 1989/1990, s. 155-177.

${ }_{18}$ M. Wa g n e r, Wojna polsko-turecka..., t. II, s. 206-208.

19 Z. Wój c i k, Rzeczpospolita wobec Turcji i Rosji 1674-1679, Wrocław 1976, s. 30, 52-53. Podsumował i rozwinął opis tych działań M. Wa g n e r, Wojna polsko-turecka..., t. II, s. 133-138. 
Niemniej koronacja i następujący po niej sejm dawały nowe nadzieje, chociaż potęga osmańska w dalszym ciągu zagrażała Rzeczypospolitej, a sprzyjający czas mijał. Szlachta zaaprobowała kierunek polityczny króla i uchwaliła wysokie podatki na kontynuację wojny. Jednak pieniądze ściągano bardzo powoli i zebrano ich znacznie mniej, niż oczekiwano. Choć kwestia dokończenia wojny z Portą zdominowała obrady sejmu, to stronnicy dworu nie omieszkali przypominać o wiarołomnym elektorze i interesach Rzeczypospolitej na północy ${ }^{20}$. Kampania 1676 r. zakończyła się skuteczną obroną obozu w Żórawnie i podpisaniem bardzo ogólnego traktatu, który następnie miał być potwierdzony.

Kolejny sejm, zgodnie z propozycjami króla, podjął decyzję o zakończeniu wojny z Portą i wysłaniu do Stambułu posła. Jego zadaniem miało być wynegocjowanie honorowych warunków zawarcia pokoju ${ }^{21}$. Monarcha nie narzucał szlachcie konieczności podpisania traktatu z Imperium Osmańskim, lecz przedstawiał ważne argumenty, których nie można było logicznie odrzucić. Równocześnie krytycznie oceniał dotychczasowe relacje z Moskwą, będące konsekwencją jej postępowania. Czynnikiem, który odegrał ważną rolę podczas debat o wysłaniu posła do Stambułu, była sytuacja na Ukrainie. W 1676 r. hetman Doroszenko porzucił sułtana i oddał tereny nad Dnieprem Moskwie. Jego następcą został kolejny raz nieudolny Jerzy Chmielnicki, co wzbudziło duży niepokój, zarówno w Warszawie, jak i w Moskwie. Decyzja sejmu o rokowaniach z Portą skłoniła Stambuł do wypowiedzenie wojny państwu carów. W Rzeczypospolitej podjęto starania, aby uniemożliwić Chmielnickiemu powiększenie swej władzy, żeby w ogóle zachować jakieś wpływy wśród Kozaków. Na skutek samowolnych decyzji i awanturniczego postępowania w 1681 r. obalono Juraszkę, którego następcą został hospodar mołdawski Jerzy Duka. Tym samym nastąpił powrót do unii mołdawsko-ukraińskiej, którą chciał stworzyć już Bohdan Chmielnicki w 1652 r. W 1681 r. realia polityczne były oczywiście zupełnie inne niż 30 lat wcześniej, ale ponownie była to koncepcja niebezpieczna dla państwa polsko-litewskiego. Trzeba jednak zaznaczyć, że sam Duka dbał o zachowanie dobrych kontaktów z Rzeczpospolitą i nie podejmował wrogich wobec niej działań, był w ogóle życzliwy Polakom. Na korzyść polską działał też fakt, że duża część Kozaków (zwłaszcza Sicz) czuła się poszkodowana porozumieniami między Imperium Osmańskim i państwem carów.

Gdy w 1682 r. w państwie carów doszło do zamieszek wewnętrznych, Sobieski postanowił wykorzystać kryzys rywala i kolejny raz podjął akcję propagandową wśród Kozaków. Raczej nie miała ona określonego celu, chodziło ogólnie o umocnienie polskich wpływów na Ukrainie, aż do obalenia promoskiewskiego hetmana Zadnieprza, Iwana Samojłowicza $^{22}$. Najważniejsze działania mieli podjąć episkop lwowski Józef Szumlański oraz Wasyl Iskrzycki. W instrukcjach dla agitatorów wskazywano na prawa Rzeczypospo-

${ }^{20}$ J. Woliń s ki, Sprawa pruska 1673-1675..., s. 205-207.

${ }^{21}$ O przygotowaniu sejmu; Instrukcja postowi na sejmik pro die 10 decembris, dana w Żótkwi dnia 3 miesiaca listopada rp 1676, B. Czart., rkps 1663, s. 547-554. Problemy te zostały omówione przez historyków; K. Matwijow ski, Pierwsze sejmy...., s. 157-162; J. S tolick i, Propaganda antyturecka w latach 1676-1683, [w:] Król Jan III Sobieski i Rzeczpospolita w latach 1674-1683, red. D. Milewski, Warszawa 2016, s. 20, 23. Przebieg sejmu omówił K. M a tw ij ow s k i, Pierwsze sejmy..., s. 195-234.

${ }^{22}$ Opinię taką wyraził Piotr K ro11, Jan III Sobieski wobec Kozaczyzny w latach 1676-1683, [w:] Król Jan III Sobieski i Rzeczpospolita w latach 1674-1683, s. 201-226. Ta opinia jest zgodna z charakterem Sobieskiego, który starał się wykorzystywać wszelkie otwierające się możliwości uaktywnienia Rzeczypospolitej, po czym, gdy okazywały się złudne lub niewielkie, zmieniał front. Źródła do tych misji znajdują się w rękopisie 1188 w Bibliotece Ordynacji Zamojskiej. 
litej do Ukrainy, zagrożenie tureckie, przed którym może jej mieszkańców ochronić król polski, instrumentalne ich traktowanie przez Moskwę. Starszyźnie przypominano o wolnościach, Kozaków zapewniono, że zagarnięte przez nich ziemie (wcześniej należące do szlachty) będą przez nich zatrzymane, a prawa prawosławnych przestrzegane na równi z prawami katolików. Szczególna rola w obaleniu władzy carskiej miała przypaść Zaporożu. Antymoskiewskie działania zakończyły się niepowodzeniem, a istotną rolę w ich stłumieniu odegrał Samojłowicz.

W 1677 r. współcześni obserwatorzy, zwłaszcza zagraniczni, oceniali, że zawarcie przez Rzeczpospolitą układu z Portą jest wstępem do wojny z państwem carów. Wnioski takie były konsekwencją określonego spojrzenia na sytuację międzynarodową w środkowo-wschodniej Europie po zawarciu traktatu andruszowskiego. Jan III wybierał inną koncepcję, która wydawała się możliwa wówczas do przeprowadzenia, czyli pokój z obydwoma sąsiadami ${ }^{23}$, dzięki czemu miały się zwiększyć możliwości zrealizowania przez króla planów bałtyckich. Wizja pokoju pociągała szlachtę, która z coraz większym trudem radziła sobie z pogarszającymi się realiami ekonomicznymi. Gwoli ścisłości trzeba dodać, że ideę współdziałania z Portą podsycała propaganda francuska, natomiast występowała przeciw niemu dyplomacja habsburska, papieska oraz brandenburska. Inspirowana przez nią opozycja rozsiewała plotki, że król zawarł układ z Portą, ponieważ porozumiał się z Ludwikiem XIV i dąży do rozpoczęcia kolejnych działań wojennych z przeciwnikami Króla Słońce. Zatem akcentowano w tej propagandzie, że pokój z Portą jest potrzebny tylko po to, aby monarcha miał możliwości prowadzenia kolejnej wojny, która ponadto nie służy polskim interesom. Można ocenić, że opinie takie zawierały trochę prawdy, ponieważ Sobieski rzeczywiście dążył do wystąpienia przeciw elektorowi. Miały tego dokonać jednak prywatne oddziały, zaciągnięte za pieniądze francuskie. Nie planował zaś wypowiedzenia wojny Brandenburgii, którą wszakże mógł później oficjalnie wywołać elektor. Były w nich też argumenty, że zawierając pokój, król dąży do wprowadzenia w Rzeczypospolitej absolutyzmu, przy pomocy Francji, Kozaków czy Tatarów. Propaganda przeciwników monarchy uderzała więc w czułe punkty szlachty. Król, żeby przekonać ją do swych działań, unikał podnoszenia spraw mogących wywołać konflikty. Zgodził się, aby na sejmie w 1677 r. nastąpiło potwierdzenie wcześniejszych układów z cesarzem i elektorem, co było jedynie symbolicznym uderzeniem w jego sekretną politykę, ale rzeczywistych negatywnych konsekwencji mu nie przyniosło. Próbował nie dopuścić do redukcji wojska, ale niechęć szlachty do utrzymania armii przeważyła nad rozsądkiem. Niemniej zwinięcie wojska przyniosło fatalne konsekwencje podczas rokowań w Stambule.

Zakończenie sejmu, które nastąpiło w maju 1677 r., stworzyło monarsze sposobność do aktywnych działań na północy. Jan III udał się do Gdańska w celu rozwiązania zatargów wewnętrznych w mieście, ale jego rzeczywistą intencją był pobyt w pobliżu Prus Książęcych, gdzie miały się rozstrzygnąć najważniejsze wydarzenia w czasie konfliktu

${ }^{23}$ Koncepcję taką przedstawił królowi jeden z najlepszych ówczesnych statystów, znawca spraw wschodnich, Franciszek Kazimierz Bieniewski. Memoriał jego autorstwa obszernie omówił Z. W ó j c i k, Rzeczpospolita wobec..., s. 37-42. 
z elektorem, których zapowiedzią było zawarcie traktatu ze Szwedami 4 VIII 1677 r. Równocześnie nastąpiły przygotowania do uderzenia Szwedów na Prusy Książęce, a miały ich wspierać oddziały polskie zaciągnięte za francuskie pieniądze. Fryderyk Wilhelm już od roku podejmował rozmaite działania, aby odsunąć zagrożenie polskie. Próbował przekonać monarchę do innych projektów lub krytycznie nastawić do jego planów opozycję. Najbardziej mu jednak pomogły w tym zamiarze nieudolne działania armii szwedzkiej. W 1677 r. nie doszło do ataku szwedzkiego, a na dodatek elektor zdobył Szczecin. Sobieski łagodził nastroje w kraju, przeciwstawiał się propagandzie brandenburskiej oraz próbował osłabiać wpływy swych przeciwników na Litwie. Przygotowania Szwedów do podjęcia kolejnych działań były nieudolne, a kiedy doszło do ataku szwedzkiego na Prusy, okazał się on kompromitacją ${ }^{24}$. Nie było więc okazji, aby Jan III miał sposobność do jakiejkolwiek interwencji.

Król polski próbował wywiązać się z innego zobowiązania. Brak możliwości podjęcia wojny z cesarzem spowodował, że niejawnie zgodził się na projekt sformowania oddziałów, które miały udzielić wsparcia antyhabsburskim powstańcom na Węgrzech. Ambasadorowie francuscy chcieli realizować te plany zaraz po elekcji Jana III, ale ulegały one opóźnieniu. Po przeprowadzeniu redukcji wojska łatwo można było zwerbować ochotników. Forbin Janson pozyskał więc Hieronima Lubomirskiego, który stanął na czele korpusu dywersyjnego. Ujawnienie w Rzeczypospolitej informacji o wsparciu dla powstańców węgierskich przyczyniło się do zwiększenia konfliktu wewnętrznego, pogłębionego przez działania dyplomacji habsburskiej, popieranej przez Stolicę Apostolską ${ }^{25}$. W tym przypadku nie musiała ona nawet działać zbyt aktywnie. Zwolennicy utrzymania dobrych relacji z cesarzem mieli silną pozycję w państwie i duże wpływy wśród szlachty, co było zresztą bardzo widoczne za panowania Jana Kazimierza. Dwór wiedeński zmobilizował swych zwolenników do powstrzymania tych działań. Zarzuty łamania prawa spadły głównie na Lubomirskiego, ale uderzyły też w monarchę, który oficjalnie odżegnywał się od współudziału w tym przedsięwzięciu. Konflikt wewnętrzny narastał i szkodził Sobieskiemu, który do wiosny 1678 r. sprzyjał działaniom posła francuskiego Bethuna i Lubomirskiego. Król naraził się na liczne zarzuty; ostro wystąpił przeciw niemu bardzo wpływowy biskup krakowski Andrzej Trzebicki. W korespondencji przeciwników dworu znajdujemy argumenty wskazujące na szkody państwa na arenie międzynarodowej, poniesione w wyniku tej akcji. Biskup Trzebicki już w 1677 r. z oburzeniem oceniał te wydarzenia, wskazując, że dzieje się to przeciw wszelkim prawom i układom, moralnym i podpisanym. Podsumował: „że to naruszenie pactorum et foedorum nie może przynieść miłej Ojczyźnie naszej nic dobrego, tylko wszystko złe"26. I dalej argumentował, że nie dotrzymujemy wiary nikomu na pohańbienie naszego narodu. W późniejszym mało znanym liście już do samego monarchy wzywał go, aby powstrzymał zaciągi, prowadzone przez posłów francuskiego i szwedzkiego. Przypomniał dymitriady, które spowodowały zaostrzenie re-

${ }^{24}$ K. Piw ars ki, Polityka bałtycka..., s. 218-240; Bardziej krytycznie ocenił działania Sobieskiego Konrad B o b i a t y ń s k i, Michał Kazimierz Pac-wojewoda wileński, hetman wielki litewski. Działalność polityczna $i$ wojskowa, Warszawa 2008, rozdz. VIII.

${ }^{25}$ K. P iw ars k i, Hieronim Lubomirski hetman wielki koronny, Kraków 1929, s. 9-17.

${ }^{26}$ Kopia listu ks. Trzebickiego, biskupa krakowskiego do wojewody wileńskiego, bd. B. Czart., TN 175 , s. 543; Kopia listu jm. ks. biskupa krakowskiego do JKMci, in februario 1678, Lwowska Biblioteka Naukowa im. Stefanyka, fond 4 (Baworowscy) rkps 299, k. 102-104. 
lacji z Moskwą. Myśli te rozwijał może mało przenikliwy statysta, kasztelan kamieniecki Gabriel Silnicki. Oceniał, że zaciąganie żołnierzy przeciw cesarzowi to pragnienie wojny z całym światem; ale jak kontynuował, ponieważ sejmu szybko nie będzie, to krok na drodze ograniczenia wolności. I to był dominujący kierunek w narracji przeciw królowi, co podkreślają inne źródła ${ }^{27}$. Działania na Węgrzech wzmocniły opozycję antykrólewską znacznie bardziej niż te skierowane przeciw elektorowi, który wykorzystał krytykę poczynań węgierskich króla i połączył swoją sprawę z cesarską, podkreślając bezprawne i szkodliwe działania Jana III. I wtedy z czasem znajdował wsparcie i obrońców. Sobieski zresztą raczej z konieczności uległ podszeptom francuskim. Był związany układem z Ludwikiem XIV, w którym wspólne działania przeciw cesarzowi były uwzględniane. Wysłanie zaciągów na Węgry w 1677 r. było bardziej konsekwencją wsparcia sojusznika niż wykorzystania tego przedsięwzięcia do osiągnięcia własnych celów. Warto przy tym zauważyć, że cesarstwo i Brandenburgia, które znajdowały się w koalicji antyfrancuskiej, miały często odrębne interesy. Habsburgowie z niechęcią obserwowali dążenia Hohenzollernów do umacniania swojej pozycji na północy Rzeszy.

$\mathrm{Na}$ początku 1678 r. Jan III porzucił ideę wojny z Brandenburgią. Król nie wierzył już w powodzenie kolejnych działań szwedzkich, zwłaszcza że do Prus ściągały wojska elektorskie z Rzeszy. Wsparcie dla Węgrów wzbudzało dalsze protesty Habsburgów. Sobieski w coraz większym stopniu dystansował się od działań Lubomirskiego. W konsekwencji mogło dojść do zawiązania antykrólewskiego spisku (nie jest to rozstrzygnięte), ale konflikt wewnętrzny na pewno prowadził do osłabienia pozycji Jana III. Ze stolic w zachodniej Europie docierały już wieści o zbliżającym się zakończeniu wojny, przede wszystkim jednak fatalne wiadomości przychodziły ze Stambułu, gdzie toczyły się rozmowy o zawarciu wiecznego pokoju.

W tym miejscu trzeba też zwrócić uwagę na kolejny problem w polityce zagranicznej Rzeczypospolitej i powrócić do spraw południowych. Ważną rolę w planach Sobieskiego odgrywały rokowania prowadzone przez Jana Gnińskiego w Stambule. Zawarcie pokoju z Portą było konieczne dla podjęcia nowych inicjatyw, a jego postanowienia powinny być dla strony polskiej honorowe. Było to konieczne dla utrzymania klimatu sprzyjającego inicjatywom monarchy. Zwięzłe i mało konkretne zapisy traktatu w Żórawnie ze względu na swą lakoniczność pozostawiały rozbieżności w ich interpretacji. W wyniku zakończenia działań wojennych w rękach tureckich pozostał jedynie Kamieniec i było oczywiste, że twierdzy tej Turcy nie zwrócą, z powodu jej znaczenia strategicznego. Miał więc Gniński starać się o utrzymanie przy Rzeczypospolitej dużej części Podola ${ }^{28}$. W wydawnictwie Franciszka Pułaskiego znajdują się listy magnatów polskich wysłane do Gnińskiego, w których prosili go, aby pamiętał o ich majątkach znajdujących się na Podolu i starał się o ich zatrzymanie. Również Sobieski zdawał sobie sprawę, że chcąc utrzymać autorytet

${ }^{27}$ List Gabriela Silnickiego do wojewody wileńskiego Michała Paca, Lwów 6 II 1678, B. Czart., rkps 416, nr 7. Wcześniej takie poglądy wyrazili np. anonimowy autor, Z Wilna die 26 XI 1677, B. Czart., TN 175, s. 513-514 lub Jan Odrowąż Pieniążek w liście do M. Paca z Krakowa 31 V 1677, ibidem, s. 245-246.

${ }^{28}$ Instrukcja Janowi Gnińskiemu od króla i stanów Rzeczypospolitej, Warszawa 7 V 1677, [w:] Źródła do poselstwa Jana Gnińskiego wojewody chetmińskiego do Turcyi w latach 1677-1678, wyd. F. Pułaski, Warszawa 1907, nr 6, Instrukcja sekretna, nr 7. Na temat starań Gnińskiego o zatrzymanie części dóbr podolskich pisałem przed laty, J. S toli cki, Egzulanci podolscy 1672-1699. Znaczenie uchodźców z Podola w życiu politycznym Rzeczypospolitej, Kraków 1994, s. 56-59. 
i wpływy, nie może dopuścić do utraty większości posiadłości podolskich. Okazało się jednak, że dygnitarze osmańscy odrzucają wszelkie argumenty. Zmusili wojewodę do zgody na pozostawienie Porcie całego Podola, co należy uznać za klęskę dyplomatyczną; zresztą traktowanie posła było upokarzające i pogłębiało tylko poczucie porażki. Gniński nie miał w dodatku żadnych argumentów w czasie rokowań; w Stambule zdawano sobie sprawę ze słabości Rzeczypospolitej, którą wyraźnie symbolizowała decyzja o zwinięciu wojska. A w przypadku niewyrażenia zgody na warunki tureckie, wezyr groził kolejną wojną i uwięzieniem posła, co zmusiło Gnińskiego do podpisania pokoju zgodnie z warunkami narzuconymi przez stronę osmańską. Rada senatu zgodziła się na to, aczkolwiek pokój podpisano, zanim jeszcze jej postanowienia dotarły do Stambułu.

Wiosną 1678 r. nastąpił więc upadek wielkich planów królewskich, co skłoniło Jana III do zmiany polityki i powrotu do idei wojny z Portą. Imperium Osmańskie prowadziło po Żórawnie wojnę z państwem carów, której celem było opanowanie Ukrainy. W latach 1677-1678 Rzeczpospolita prowadząca rokowania nie mogła udzielić Moskwie pomocy, a w początkowym okresie nie było to też zgodne z planami bałtyckimi króla. Zapowiedzią jednak nowych działań Jana III był jego list do papieża Innocentego XI z 16 kwietnia 1678 r. ${ }^{29}$ Król usprawiedliwiając się, wskazywał, że podpisanie traktatu było koniecznością, ale przedstawił też papieżowi ideę powołania koalicji antytureckiej, w skład której weszłyby państwa chrześcijańskie.

Plany międzynarodowe, jakie podjął Jan III, dążąc do realizacji nowych zamierzeń w polityce zagranicznej, łączyły się z działaniami wewnętrznymi. Sejm w Grodnie musiał zaakceptować niedawno zawarty pokój z Portą w Stambule. Ponadto na tym sejmie Sobieski powinien przedstawić szlachcie nowy program polityczny. Dodatkowo obowiązkiem króla było zapewnienie ochrony jego wcześniejszym sojusznikom, głównie Hieronimowi Lubomirskiemu, a także wygaszenie nabrzmiałych konfliktów wewnętrznych. Działania te zakończyły się powodzeniem.

W legacji na sejmiki przedsejmowe oraz w propozycji od tronu Sobieski jedynie zarysował sytuację i nie postulował podjęcia działań przeciw Porcie. Kiedy Gniński przedstawił relację z poselstwa w Stambule, nie spotkało się ono z krytyką. Równocześnie król załagodził spory, w tym ten między Lubomirskim a hetmanem wielkim Dymitrem Wiśniowieckim. Nie doszło również do zaostrzenia konfliktu ambasadorów francuskiego i cesarskiego. Monarcha jednak wyraźnie odchodził od dotychczasowej polityki, czego świadectwem była mowa od tronu, wygłoszona 28 lutego 1679 r. ${ }^{30}$ Król zaproponował wysłanie poselstw do państw europejskich z zamiarem stworzenia koalicji antytureckiej oraz wezwał do uchwalenia podatków na cele wojenne. Równocześnie obserwował rozwój sytuacji na Ukrainie i, być może, wyczekiwał na dogodną sytuację do interwencji w wojnie rosyjsko-tureckiej. Sejm uchwalił skrypt ad archivum, w którym podjęto decyzję o wysłaniu posłów do władców chrześcijańskich, aby przedstawić zagrożenie tureckie i prosić

${ }^{29}$ „Jan III do Innocentego XI z Lublina”, Źródta do poselstwa..., s. 331-332.

${ }^{30}$ Zdanie JKMci w senacie czytane die 28 II, B. Czart., TN 177, s. 323-331, druk: Źródła do poselstwa..., s. $431-436$. 
o posiłki na wojnę z Portą. „Także do cara moskiewskiego wyprawi ablegatów starając się pilnie, aby coniunctio armorum z tym narodem przeciwko powszechnemu Krzyża Św. nieprzyjacielowi dojść mogło" ${ }^{\text {"1 }}$. Można więc ocenić, że kompromis zawarty na sejmie nie tylko nie okazał się porażką monarchy, ale wręcz odwrotnie, przyniósł mu sukces ${ }^{32}$. Król wybrnął z trudnej sytuacji bez ujmy dla autorytetu i szkody dla swych zwolenników, w dodatku zaskoczył przeciwników zmianą koncepcji i narzucił kierunek działań, które niedługo zostaną uwieńczone sukcesem. Wykazał się przenikliwością w diagnozach i skutecznymi receptami z pożytkiem dla Rzeczypospolitej. Natomiast polityka bałtycka została przegrana wcześniej i na sejmie już nie warto było z tego powodu narzekać. Równocześnie Sobieski podjął kroki, by przekonać społeczeństwo, że wznowienie wojny z Portą służy interesom Rzeczypospolitej i zerwanie dopiero co podpisanego traktatu jest nie tylko korzystne, ale i niezbędne. Spotkały się one z pewną życzliwością szlachty, którą jednak trzeba było przekonywać, że wojna jest nieuchronna, ale też zaszczepić jej ideę walki za wiarę. Zmęczona ciągłymi wojnami (niemal bez przerwy od 1648 r.) szlachta oczekiwała bowiem spokoju.

Monarcha, zakładając, że osamotniona Rzeczpospolita nie jest w stanie pokonać Imperium Osmańskiego, szukał sojuszników, aby wykorzystać koniunkturę międzynarodową. Niemniej akcentował, że nie należy zaniedbywać własnych przygotowań. Ważną rolę w strategii pozyskania zwolenników odgrywała propaganda. Podkreślano nieuchronność kolejnej wojny z Portą, konieczność przygotowania państwa do niej oraz jego usprawnienia, czemu miało służyć zwiększenie królewskiej władzy wykonawczej.

Historycy zwrócili uwagę na pismo Rozmowa czyli dyjalog ziemianina z statystą prezentujące najważniejsze elementy programu Jana III w tym czasie. Imperium Osmańskie jest państwem prowadzącym agresywną politykę wobec sąsiadów, czego potwierdzeniem są rokowania Gnińskiego w Stambule. Trzeba wykorzystać chwilowy pokój i przygotować się do wojny, a w tym celu oddać pewne uprawnienia dotyczące spraw obronnych w ręce króla.

Z kolei w piśmie Nie tak racyje, jako same necessitates, które na tym sejmie do obmyślenia defensionis publicae obowiązuja stany tej $R P^{34}$ podkreślono konieczność usunięcia Turków z Podola. Przypominano agresywne działania Turków, którzy podczas rozgraniczenia granicy zagarnęli ziemie do Podola nienależące. Ponownie spotykamy argumenty o gotowości nieprzyjaciela do wojny i naszym braku przygotowania. Najskuteczniejszym środkiem miała być koligacja z carem, a gdy nie uda się jej przeprowadzić, współdziałanie z monarchami chrześcijańskimi. Podczas sejmu należy ukazać gotowość do wojny, gdyż w innym przypadku żaden władca nie będzie skłonny rokować z nami. Polacy muszą dać

${ }^{31}$ Skrypt ad archivum na sejmie w Grodnie dany względem wojny tureckiej, B. Czart., TN 176, s. 387-389.

${ }^{32}$ Krytyczną opinię przedstawili ongiś uznani badacze Jana III: Z. W ó j c i k, Jan Sobieski..., s. 291-292; K. Matwijowski, Sejm grodzieński 1678-1679, Wrocław 1985, s. 110-121. Niedawno wyraziłem osąd bardziej przychylający się do oceny Kazimierza Konarskiego, który uznał sejm za wielki sukces monarchy; J. S t 1 l i c k i, Propaganda antyturecka..., s. 26-27. K. K o n a r s k i, Polska przed odsiecza wiedeńska, Warszawa 1914, s. 49-59.

${ }^{33}$ Rozmowa czyli dyjalog ziemianina z statysta o pokoju z Turczynem zawartym i o przyszlych majacych nastapić rzeczach, BN 6897. Z. W ó j cik, Rozmowa ziemianina ze statysta, ,Śląski Kwartalnik Historyczny Sobótka", R. XXX: 1975, s. 321-333.

${ }^{34}$ B. Czart., TN 178, s. 707-724. 
przykład dla postronnych władców. Przygotowania nie tylko uchronią Rzeczpospolitą od zguby, ale i zyska ona respekt, zarówno wśród Turków, jak i sąsiadów.

W 1680 r. doszło do wytyczenia nowej polsko-tureckiej granicy, ponieważ trzeba było oddzielić Podole (już osmańskie) od Rzeczypospolitej. Podczas rozgraniczenia dygnitarze osmańscy wykazali się zaborczością i prawem silniejszego zagarnęli kilka ziem nienależących do Podola, co spowodowało wzrost nastrojów antytureckich. Z drugiej strony w źródłach znajdujemy opinie niechętne wspomnianym postawom, ponieważ obawiano się zerwania pokoju i nowej wojny z Imperium Osmańskim ${ }^{35}$.

W latach 1678-1682 w Rzeczypospolitej ścierały się poglądy propagujące podjęcie działań wojennych z antywojennymi. Poselstwa wysłane do państw chrześcijańskich nie przyniosły żadnych efektów. Wojna Moskwy z Imperium Osmańskim zbliżała się do końca. Równocześnie Porta wykazywała agresywne zamiary wobec Rzeczypospolitej. Współcześni akcentowali ogromne niezadowolenie dostojników tureckich z powodu polskiej aktywności międzynarodowej i wysłania wspomnianych poselstw. Na sejm w $1681 \mathrm{r}$. monarcha przygotował propozycje kolejnych działań dyplomatycznych, mających przybliżyć zbudowanie koalicji antytureckiej. Obrady upływały jednak w dużym nieładzie, dominowała prywata, a plany stworzenia ligi też budziły wiele zastrzeżeń, i choć ich finałem był projekt konstytucji, to pod koniec maja doszło do zerwania obrad ${ }^{36}$. Sejm został unicestwiony za pieniądze brandenburskie, ale i nie bez inspiracji francuskiej. Król, odbierając to jako ciężki cios, wyciągnął wniosek, że w przyszłości nie tylko powinien zatroszczyć się o zawarcie przymierza antytureckiego, ale musi też chronić sejm przed zerwaniem przez przeciwników.

Sytuacja międzynarodowa zmieniła się latem 1682 r. Poparcie Porty dla powstańców węgierskich oznaczało wypowiedzenie wojny cesarzowi. Spowodowało to, że Habsburgowie w obliczu zagrożenia tureckiego zmuszeni byli szukać sojuszników. Klimat w Rzeczypospolitej dla zawarcia układu był sprzyjający, co było konsekwencją podjętych przez Jana III starań. Dodatkowo zaangażowanie Turków na Węgrzech umocniło wśród szlachty przekonanie o zagrożeniu dla Krakowa. W 1683 r. podczas sejmu toczyły się rokowania, w wyniku których doszło do podpisania przymierza z Habsburgami. Celem Jana III było uratowanie sejmu przed zerwaniem, co dzięki przemyślanej taktyce udało się osiągnąć. Urzeczywistniony został plan Sobieskiego, który próbował realizować od połowy $1678 \mathrm{r}$. Rzeczpospolita wystąpiła przeciw Imperium Osmańskiemu jako jeden z członów koalicji państw chrześcijańskich. Na opłacenie armii otrzymała spore subsydia papieskie. Dodatkowo wojska polskie, ruszając na odsiecz Wiednia, miały bić się na obcej ziemi i w przeciwieństwie do poprzedniej wojny uchronić własną ludność od jej okrucieństw.

K. Piwarski zwrócił uwagę na znaczne ożywienie dyplomacji polskiej po elekcji Jana III. Rzeczpospolita włączyła się w szersze kręgi polityki międzynarodowej, co w porównaniu z epoką wcześniejszą stanowiło wyraźny przełom ${ }^{37}$. Historycy wysoko oceniali kompeten-

35 J. S tolicki, Egzulanci podolscy..., s. 72-75.

${ }^{36}$ Skrypt ad archiwum respectu foederis offensivi z Moskwą contra Ottomanos, B. Czart., TN 176, s. 655-662. Sejm w 1681 r. ciągle czeka na opracowanie. O propagandzie antytureckiej J. S t o li c k i, Propaganda antyturecka..., s. 29-31.

${ }^{37}$ K. P iw ar s ki, Ostabienie znaczenia..., s. 240-242. 
cje Jana Sobieskiego, które zaowocowały otwartością na podjęcie nowych inicjatyw oraz dużym rozmachem planowanych działań, co wskazuje na jego polityczne wizje. Trzeba zaznaczyć, że odebrane przez króla wykształcenie, jego kwalifikacje oraz szerokie horyzonty umysłowe sprawiły, że mógł realizować wybitne koncepcje polityczne. Warto tu też podkreślić dużą wiedzę historyczną i geograficzną króla, co dawało mu lepszą orientację w realiach geopolitycznych.

Polityka bałtycka, określona przez historyka jako „Wielkie plany królewskie”, przyniosła Sobieskiemu niepowodzenia we wszelkich przedsięwzięciach. Wojna turecka, jaką odziedziczył po swoim poprzedniku, ograniczała jego inicjatywę i uniemożliwiła mu podjęcie aktywnych działań na północy, które otworzyły się dzięki korzystnej sytuacji międzynarodowej. Jan Sobieski przygotowywał się do nich niemal od elekcji, prowadząc rokowania z Ludwikiem XIV, których skutkiem były układy w Jaworowie i Gdańsku. Podjął też określone kroki w sprawach wewnętrznych, w stopniu, jaki umożliwiał ustrój państwa. Wyczekiwał na dogodny moment, ale zmiany w Europie nie ułożyły się korzystnie. Początkowo sprzyjająca sytuacja międzynarodowa z biegiem czasu zaczęła się pogarszać, zaś sytuacja na zachodzie Europy dojrzewała do zakończenia konfliktu. Działania Szwedów były wyjątkowo nieudolne i sojusznik ten okazał się zawodny. Trzeba wyraźnie podkreślić, że działania Jana III nie spowodowały negatywnych konsekwencji dla Rzeczpospolitej, a polityki tej nie można nazwać awanturniczą. Ponadto, kiedy sytuacja zaczęła się zmieniać, Sobieski zrezygnował z planów antybrandenburskich i popierania powstańców węgierskich. Polityka bałtycka przyniosła pewne niepokoje w sprawach wewnętrznych, ale były one raczej konsekwencją systemu politycznego, co zresztą zostało już opracowane przez historyków. Należy więc pozytywnie ocenić działania króla, który próbował wykorzystać dobrą koniunkturę, ale kiedy załamała się, nie trzymał się przegranej opcji, lecz zmienił kierunek polityki. Imperium Osmańskie nie zamierzało bowiem porozumieć się z Rzeczpospolitą, lecz wymuszało kolejne nabytki. Rodziło to przekonanie w Polsce, że do nowej wojny wkrótce dojdzie, a opinię publiczną zręcznie urabiał król. Przygotowania do nowej wojny z Portą trwały kilka lat, zaś koncepcja koalicji, której król był pomysłodawcą i wraz z papieżem Innocentym XI włożył najwięcej inicjatywy w jej realizację, ziściła się w końcu w 1683 r. Sobieski nie kierował się dyrektywami Watykanu, lecz sam starał się wpływać na decyzje papieża. Urzeczywistnienie tych planów, aczkolwiek określa się je jako „malum necessarium”, było zgodne z polską racją stanu ${ }^{38}$. Warto też przypomnieć o znaczeniu odsieczy wiedeńskiej dla zmian w sytuacji geopolitycznej na południu Europy oraz w świadomości narodów bałkańskich w kolejnych wiekach.

\section{Bibliografia}

Źródła rękopiśmienne:

Biblioteka Czartoryskich w Krakowie:

Teki Naruszewicza 172, 175, 176, 177, 178

rękopisy 416, 423, 431, 1663

Biblioteka Narodowa w Warszawie:

rękopis 6897

38 Opinię tę wyraził Z. W ój c i k Jan Sobieski..., s. 316. Określenia „dyrektywy Watykanu” użył K. P iw a r s ki, Osłabienie znaczenia..., s. 245, ale wynika ono z czasu, w którym został napisany artykuł. 
Biblioteka Ordynacji Zamojskiej 1188

Lwowska Biblioteka Naukowa im. Stefanyka:

fond 4 (Baworowscy) rękopis 299

Źródła drukowane:

Źródta do poselstwa Jana Gnińskiego wojewody chetmińskiego do Turcyi w latach 1677-1678, wyd. F. Pułaski, Warszawa 1907.

Literatura:

Bobiatyński Konrad, Michał Kazimierz Pac - wojewoda wileński, hetman wielki litewski. Działalność polityczna i wojskowa, Warszawa 2008.

Chowaniec Czesław, Sobieski wobec Tatarszczyzny 1683-1685, Kwartalnik Historyczny, R. XLII: 1928, s. 52-66.

Chowaniec Czesław, Z dziejów powiedeńskiej polityki Jana III na bliskim Wschodzie, Kwartalnik Historyczny, R. XL: 1926, s. 151-160.

Czamańska Ilona, Oswobodziciel czy najeźdźca? Polityka Jana III Sobieskiego wobec hospodarstw Mołdawii i Wołoszczyzny, „Roczniki Historyczne”, R. LV-LVI: 1989/1990, s. 155-177.

Karwat Izabela, Dyplomacja francuska w Rzeczypospolitej w dobie bezkrólewia i elekcji 1673-1674, Kraków 2011 (praca magisterska Zakład Historii Polski Nowożytnej IH UJ).

Konarski Kazimierz, Polska przed odsiecza wiedeńska $r$. 1683, Warszawa 1914.

Kroll Piotr, Jan III Sobieski wobec Kozaczyzny w latach 1676-1683, [w:] Król Jan III Sobieski i Rzeczpospolita w latach 1674-1683, Warszawa 2016, s. 201-226.

Matwijowski Krystyn, Pierwsze sejmy z czasów Jana III Sobieskiego, Wrocław 1976.

Matwijowski Krystyn, Sejm grodzieński 1678-1679, Wrocław 1985.

Piwarski Kazimierz, Hieronim Lubomirski hetman wielki koronny, Kraków 1929.

Piwarski Kazimierz, Osłabienie znaczenia międzynarodowego Rzeczypospolitej $w$ drugiej połowie XVII w., „Roczniki Historyczne”, R. XXIII: 1957, s. 221-258.

Piwarski Kazimierz, Polityka battycka Jana III w latach 1675-1679, [w:] Księga pamiątkowa ku czci Profesora dra Wacława Sobieskiego, Kraków 1932, t. I, s. 197-265.

Stolicki Jarosław, Egzulanci podolscy 1672-1699. Znaczenie uchodźców z Podola w życiu politycznym Rzeczypospolitej, Kraków 1994.

Stolicki Jarosław, Propaganda antyturecka w latach 1676-1683, [w:] Król Jan III Sobieski i Rzeczpospolita w latach 1674-1683, Warszawa 2016, s. 19-33.

Wagner Marek, Wojna polsko-turecka w latach 1672-1676, Zabrze 2009, t. I-II.

Woliński Janusz, Król Jan III a sprawa Ukrainy 1674-1675, Warszawa 1934.

Woliński Janusz, Król Jan III Sobieski. W 250-letnia rocznicę śmierci, Warszawa 1946.

Woliński Janusz, Z dziejów wojny i polityki w dobie Jana Sobieskiego, Warszawa 1960.

Wójcik Zbigniew, Dyplomacja polska w okresie wojen drugiej połowy XVII w. (1648-1699), [w:] Historia dyplomacji polskiej, t. II, 1572-1795, Warszawa 1982, s. 163-330.

Wójcik Zbigniew, Jan Sobieski 1629-1696, Warszawa 1983.

Wójcik Zbigniew, Poland and Russia in the 17th Century. Problems of Internal Development, [w:] Poland at the 14 $4^{\text {th }}$ Congress of Historical Sciences in San Francisco, Wrocław 1974.

Wójcik Zbigniew, Rozmowa ziemianina ze statysta, „Śląski Kwartalnik Historyczny Sobótka”, R. XXX: 1975, s. 321-333.

Wójcik Zbigniew, Rzeczpospolita wobec Turcji i Rosji 1674-1679, Wrocław 1976.

Wójcik Zbigniew, Traktat andruszowski 1667 roku i jego geneza, Warszawa 1959.

Wójcik Zbigniew, Zmiana w układzie sit politycznych $w$ Europie środkowo-wschodniej $w$ drugiej połowie XVII wieku, „Kwartalnik Historyczny”, R. LXVII: 1960, s. 25-57. 
Jarosław Stolicki

\section{John III Sobieski's endeavors to increase the Commonwealth's influence in Europe, 1674-1683}

Summary

John III Sobieski's reign has been marked by a surge in the Commonwealth's international activity. It was a direct consequence of the King's political plans. First, he sought a prompt termination of the war with the Ottoman Port, but his attempts were ultimately unsuccessful. Later, in a secret alliance with Louis XIV, Sobieski tried to effectuate his grand plans in the Baltic, but the awaited favorable arrangement of international interests did not occur. This disappointment drove John III again towards the war with Port, with whom the Commonwealth had in the meanwhile concluded a highly unfavorable peace treaty. The king has made an effort to mobilize popular support among the gentry for his war plans. Realistically assessing the Turkish military power, he also recognized the necessity of finding allies. His concurrent attempts to convince other European rulers to join forces finally met with success in 1683 .

Key words: John III Sobieski, Polish-Ottoman Wars, Baltic politics, Anti-Ottoman coalition. 